\title{
North Platte River-South Platte River Confluence Area Drainage System History as Determined by Topographic Map Interpretation: Western Nebraska, USA
}

\author{
Eric Clausen ${ }^{1}$ \\ ${ }^{1}$ Independent Researcher, Jenkintown, PA \\ Correspondence: Eric Clausen, 100 West Ave D-17, Jenkintown, PA 19046, USA. E-mail: \\ eric2clausen@gmail.com
}

Received: April 19, 2020

Accepted: June 30, 2020

Online Published: August 31, 2020

doi:10.5539/jgg.v12n2p28

URL: http://dx.doi.org/10.5539/jgg.v12n2p28

\begin{abstract}
Detailed topographic maps of the western Nebraska North Platte River-South Platte River confluence area show a low relief and gently sloping southeast-oriented upland surface, asymmetrical drainage divides, nearly adjacent and parallel east-oriented North and South Platte River valley segments, barbed tributaries, and shallow divide crossings (low points along drainage divides) in a region south of the Nebraska Sand Hills and at the Nebraska loess region's western margin. Published interpretations of North and South Platte River confluence area landforms (referred to as the accepted paradigm) do not explain most drainage features and are compared with a new paradigm's interpretations to determine which of the two paradigms explains the regional drainage history and related surface features in a simple and consistent manner. New paradigm interpretations require large sheets of slowly-moving southeast-oriented water to have flowed toward what was probably an actively eroding Republican River valley and to have shaped the upland surface while the Platte and North and South Platte River valleys eroded headward into and across the region so as to create the asymmetric drainage divides, barbed tributaries, and shallow divide crossings. These new paradigm interpretations are consistent with each other and with recently published new paradigm interpretations of upstream North and South Platte River drainage system history. New paradigm interpretations also suggest the adjacent Nebraska Sand Hills developed on a large flood deposited delta (typical of sand dune areas on former glacial lake deltas further to the north) and the slowly-moving sheets of water may have been responsible for some or all of Nebraska's loess deposits, although the new paradigm leads to a fundamentally different middle and late Cenozoic regional geologic and glacial history than what workers using the accepted paradigm have described.
\end{abstract}

Keywords: Asymmetric Drainage Divide, Geomorphology, Loess, Nebraska Sand Hills, Republican River

\section{Introduction}

\subsection{Statement of the Problem}

To a geomorphologist the Platte River drainage system in Colorado, Wyoming, and Nebraska (shown in figure 1) poses several puzzling questions. For example, why does the North Platte River begin in north central Colorado and then flow in a north direction before turning to flow in a southeast direction? Or, why do South Platte River headwaters flow in a southeast direction before turning in a north-northeast and then a northeast direction? Or, why are the southeast-oriented Colorado River headwaters (flowing to the Pacific Ocean) located between northoriented North Platte River headwaters and southeast-oriented South Platte River headwaters (both flowing to the Gulf of Mexico)? Or, why does the Laramie River flow in a north direction to join the southeast-oriented North Platte River? Or why do the North and South Platte Rivers and some of their tributaries flow through canyons (cut across mountain ranges and other large geologic structures)? Or, why do the divergent North and South Platte Rivers join in western Nebraska to form the Platte River? These questions and many others arise because many North and South Platte River drainage system features like those in many other drainage systems represent anomalous evidence the commonly accepted paradigm does not explain. 


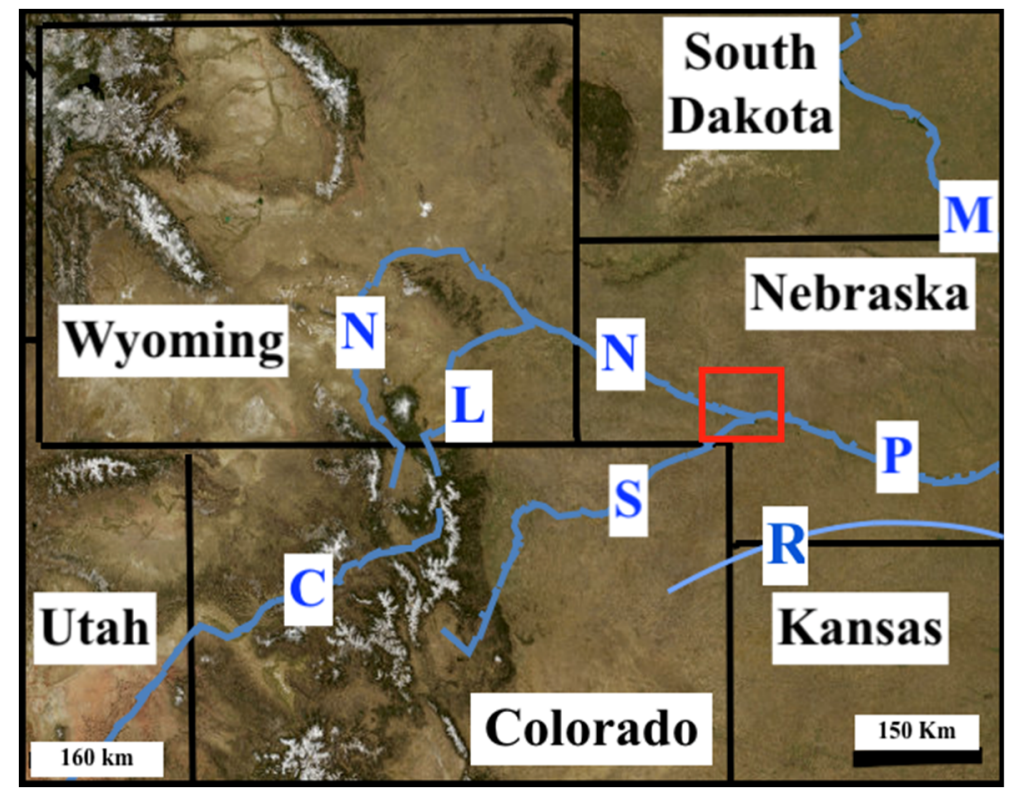

Figure 1. Modified United States Geological Survey (USGS) National Map website imagery showing the study region location (red rectangle). Blue letters identify major rivers: C-Colorado, L-Laramie, M-Missouri, N-North Platte, P-Platte, R-Republican, and S-South Platte

Scientific paradigms are sets of rules and assumptions used to govern a discipline's research efforts and Kuhn (1970) suggests anomalous evidence is dealt with in one of three ways: first the accepted paradigm eventually explains the problem evidence and the paradigm continues without serious interruption; second, the problem evidence is shelved and left for future consideration; and third, a new paradigm (which is able to explain the anomalous evidence) emerges and a battle over which paradigm to use begins. According to Kuhn paradigms by themselves are neither correct nor incorrect and should not be used to judge each other, but should be judged based on their ability to explain evidence and to open up new research opportunities. Due to unanswered drainage history questions, such as those in the North and South Platte River drainage system, a new geomorphology paradigm (new paradigm) has emerged. The new paradigm is fundamentally different from the accepted geomorphology paradigm (accepted paradigm) and leads to a different middle and late Cenozoic geologic and glacial history than what researchers following accepted paradigm rules have described.

The confluence area in western Nebraska (where the southeast-oriented North Platte River and the northeastoriented South Platte River come together to form the Platte River) may provide critical information related to how the North Platte River and South Platte River drainage systems originated. While upstream headwaters and tributaries have different orientations the North Platte River flows in a southeast direction for almost 400 kilometers before joining the South Platte River and the South Platte River flows for almost 250 kilometers in a northeast direction before joining the southeast-oriented North Platte River (see figure 1). No matter how the upstream North and South Platte River drainage systems evolved, the southeast-oriented downstream North Platte River and northeast-oriented downstream South Platte River segments must in some way have originated in what is today the confluence area. Detailed topographic maps of that confluence area show divide crossings (low points along drainage divides), asymmetric drainage divides, barbed tributaries, and other erosional landform features offering clues as to how the southeast-oriented North Platte River and northeast-oriented South Platte River valleys originated. This paper compares how the accepted and new geomorphology paradigms permit that detailed topographic map evidence to be interpreted.

\subsection{Study Region Physical Geography}

The study region is shown in more detail in figure 2 and is where the southeast-oriented North Platte River (NP) and northeast-oriented South Platte River (SP) approach each other and then both turn to flow in an east direction and nearly adjacent to each other for approximately 70 kilometers before meeting to form a southeast-oriented Platte River segment. Notice the asymmetrical South Platte River-Republican River drainage divide located on the South Platte River valley edge with extremely long tributaries flowing in roughly parallel southeast directions to the Republican River (which eventually joins the east-oriented Kansas River). South of the South Platte River- 
Republican River drainage divide are discontinuous sand dune areas with the labeled area in the figure 2 southeast quadrant known as the Lincoln County Dune Field and unlabeled dune fields in the figure south center as the Imperial Dune Fields and the dunes near the figure 2 southwest corner known as the Wray Dune Field. The North and South Platte River confluence area is at the western margin of extensive central and eastern Nebraska loess deposits and loess is present throughout the confluence area. Between the converging North Platte and South Platte Rivers are Rush Creek (R) and Ash Hollow (A) which have interesting drainage routes that flow in southeast and then north directions to join the southeast-oriented North Platte River as barbed tributaries while Lodgepole Creek is also interesting because it flows in an east direction from the Wyoming Laramie Range crest into western Nebraska and then turns in a south direction to join the northeast-oriented South Platte River. To the north of the North Platte River is the extensive Nebraska Sand Hills area where sand dunes now bury many former surface drainage routes, although Blue Creek (B) and at least some other unlabeled surface drainage routes have southeastoriented segments.

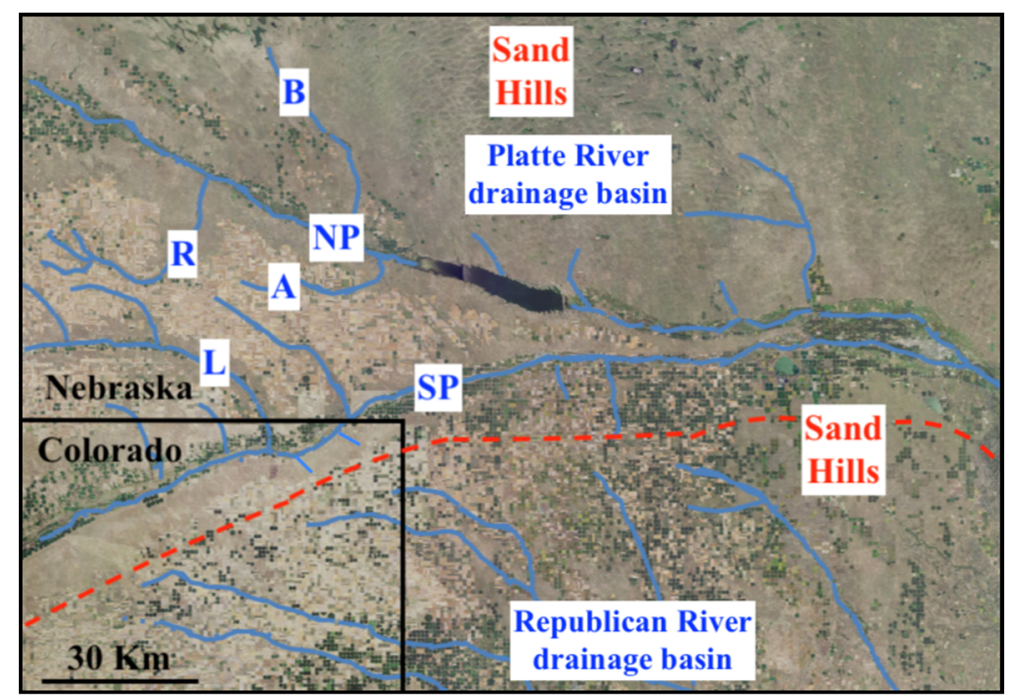

Figure 2. Modified USGS National Map website imagery of this paper's study region. Letters identify drainage routes: A-Ash Hollow, B-Blue Creek, L-Lodgepole Creek, NP-North Platte River, R-Rush Creek, and SP-South Platte River. Red dashed line shows approximate position of the South Platte River-Republican River drainage divide

The North Platte River flows into the study region as a southeast-oriented braided river on the floor of a 3- to 6kilometer wide valley slightly more than 100 meters deep with slightly higher and steeper walls to the southwest than to the northeast. As seen in figure 2 the North Platte River has been dammed by a 162-foot (49 meter) high dam to form a 22 mile (35 kilometer) long lake known as Lake McConaughty (Pabian et al, 1981). Downstream from the dam the North Platte River turns in an east direction and flows parallel to and nearly adjacent to an eastoriented South Platte River segment for almost 70 kilometers before the two rivers come together to form a southeast-oriented Platte River segment. Elevations along the North Platte-South Platte River drainage divide generally decrease and are about 50 meters higher than valley floor elevations near where the two rivers actually meet. The South Platte River also flows as a braided river in a slightly shallower, but similar valley usually with higher and steeper north walls than south walls. Further, the South Platte River-Republican River drainage divide is slightly lower in elevation than the North Platte River-South Platte River drainage divide (except near where the North and South Platte Rivers come together and meet). With the exception of the valleys of the two rivers and their larger tributaries (and in the sand dune areas) the study region upland surface is an almost featureless plain rising gradually to the west and to the south of the South Platte River the plain has a very gentle southeast-oriented slope.

\subsection{Previous Work}

The most significant previous work related to this paper resulted in the detailed topographic maps now available at the United States Geological Survey (USGS) National Map website. These maps show the region's present-day drainage system and can be used to identify drainage divides and other erosional and depositional landform features. Surprisingly, in spite of excellent topographic maps few geomorphologists now use the topographic map 
information in their published reports. Earlier geomorphologists did observe a northwest-southeast alignment of streams throughout the Great Plains region and Thornbury $(1965$, p. 306) describes how various investigators including Russell (1929) and Flint (1955) in various ways attributed this alignment to the influence of prevailing northwesterly winds. More recently Diffendal (1994, p. 141) noted "long axes of hills and valleys trending N40 $50^{\circ} \mathrm{W} \ldots$ on shales, sandstones, and most eolian sands" and a second trend where parabolic dune long axes "are $>\mathrm{S} 50^{\circ} \mathrm{E} \ldots$ on hill tops and dunes on the south side of the North Platte Valley in Keith County [seen, but not labelled in figure 3] below the loess capping the adjacent tablelands to the south. If winds are largely responsible for both sets of trends, as they appear to be, then either two periods of eolian activity are indicated or perhaps the prevailing wind direction was affected by proximity of the river valley." Clausen (e.g. 2017, 2018a), who uses a new paradigm perspective, attributed the stream alignment in regions further to the north to massive southeastoriented meltwater floods.

The Geologic Bedrock Map of Nebraska (Burchett, 1986) shows the Miocene Ogallala Formation as the surface bedrock throughout much of western Nebraska including all of this paper's study region. Diffendal's (1991) map describes the Ogallala Formation as "predominantly fluvial deposits of silt, siltstone, sand, sandstone, pebbly sand, pebbly sandstone, gravel, and conglomerate," and shows most areas to the north of where the North and South Platte Rivers meet to be covered by sand with most areas between the two rivers and some areas to the south of the South Platte River to be covered by eolian silt and sandy silt mapped as Peoria Loess. The Swinehart and Diffendal (1997) map of the area just to the west shows "wind deposited silt and sandy silt" mapped as Holocene to middle (?) Pleistocene loess that covers the region between the two rivers to the east of Rush Creek (which may correlate with the Peoria Loess) and with the Ogallala Formation exposed on the surface further to the west. Their map shows sand covering most of the surface to the north of the North Platte River and the North Platte River and Blue Creek valleys to have eroded down into the lower Oligocene Brule Formation, which underlies an unconformity at the Ogallala Formation base. The Scott (1978) map shows study region areas immediately south of the South Plate River with discontinuous areas of Pleistocene Peoria Loess (associated with the Pinedale and Bull Lake Glaciations) and Holocene and Pleistocene eolian sands covering the Ogallala Formation bedrock.

Previous investigators have suggested geologic structures determined some study region drainage route locations. Diffendal (1980, p. 123) states "Detailed field mapping of outcrops... has revealed a drop of more than $60 \mathrm{~m}$ (200 $\mathrm{ft})$ in $4.8 \mathrm{~km}(3 \mathrm{mi})$ in the elevation of the contact between the [Oligocene] Brule Formation and the [Miocene] Ogallala Group as exposed on the east side of Rush Creek. ...The unusually long valley of Rush Creek runs along the axis of a plunging synclinal fold within the structural basin, which probably controls the position of springs in the Ogallala Group feeding the only large perennial stream on the south side of the North Platte River in Garden County." Swinehart et al (1985) used subsurface data and Pliocene sand compositions to suggest structural features influenced western Nebraska paleo-drainage route positions and say (p. 223) "The modern North Platte River from the Wyoming-Nebraska state line to Garden County follows a trend that was established near the end of the Miocene by a valley in the uppermost part of the Ash Hollow" Formation [the Ash Hollow Formation in the paper refers to the uppermost 183 meters of the Ogallala Group]. They continue (p. 226), "Later in the Pliocene the anticlinal part of this [Rush Creek] structure was breached and the ancestral North Platte River assumed its southeastward course." However, the Diffendal et al paper does not address the adjacent upstream southeastoriented Rush Creek headwaters and the Swinehart et al paper hardly mentions the Nebraska South Platte River and does not address how the North and South Platte River drainage systems upstream from Nebraska originated.

The Nebraska Sand Hills immediately to the north of the North Platte River in this paper's study region is the largest of many North America's stabilized eolian sand dune areas. Muhs and Wolfe (1999, p. 187) state, "the distribution of dune fields, proglacial lakes, and inflow channels that created deltas in the lakes of southern Manitoba and North Dakota supports the hypothesis that glaciolacustrine deposits, especially sandy deltaic sediments, are the main sources of much dune sand in the northern Great Plains." The Nebraska Sand Hills are located to the south of any recognized proglacial lakes and some workers have suggested the sand source was from the Ogallala Formation and other workers have suggested a fluvial source. Ahlbrandt and Fryberger (1980) considered the data too limited to determine the sand source. Regardless of the Sand Hills sand source there have been proposals the Sand Hills once extended further to the south. Muhs et al (2000, p. 214) compare the geochemical compositions of Nebraska Sand Hills sands with the sand compositions in dune areas to the south of the South Platte River and suggest "the Nebraska Sand Hills... migrated this far south by complete infilling of what were probably perennially dry North Platte and South Platte river valleys. Such a series of events would have required an extended drought, both for activation of eolian sand and decreased discharges in the Platte River system." Based on a sand dam now blocking Blue Creek they propose the North and South Platte Rivers were dammed about 12,000 years before present. 
While investigators working from the accepted paradigm perspective have yet to explain most details related to how the upstream North and South Platte River drainage systems originated a series of recent papers written from the new paradigm perspective have done so. Clausen (2018b) shows how a large complex of anastomosing bedrock-walled canyons crossing the Laramie Range and the Goshen Hole escarpment-surrounded basin document how massive east-oriented floods once crossed the Laramie Range to reach the North Platte River. Clausen (2019a) uses topographic map evidence to demonstrate how headward erosion of the southeast-oriented North Platte River valley beheaded and reversed south oriented flood flow channels that had carved deep valleys across the northern Laramie Range. Clausen (2020a) describes how headward erosion of south-oriented valleys from an actively eroding South Platte River valley and a north-oriented valley from an actively eroding North Platte River valley captured flood flow in a large east-oriented anastomosing channel complex located between the Laramie Range and the North and South Platte River confluence area. Clausen (2020b) describes how Colorado mountain passes record how large floods once flowed in a south direction from what is now the north-oriented North Platte River headwaters area across what is today the Colorado River headwaters area to reach what are now southeast-oriented South Platte River headwaters areas. Additional papers written from the new paradigm perspective (e.g. Clausen, 2020c) document how south-oriented floods moved along what is today the southcentral Wyoming north-oriented North Platte River alignment. These and other papers suggest the new paradigm has the ability to explain upstream North and South Platte River drainage system feature origins.

\section{Research Method}

The new paradigm was developed after two multi-year systematic studies of detailed topographic maps covering the entire Missouri River drainage basin and that also included areas in several adjacent drainage basins. These studies determined how drainage divides (located between streams large enough to be shown on the detailed topographic maps) originated. Topographic map interpretation techniques used during the studies began by locating low points (referred here as divide crossings) along drainage divides where prior to drainage divide formation water once crossed what is now a drainage divide. The former flow direction could be determined if the drainage divide is today an asymmetric divide or if one valley leading from the divide crossing now drains as a barbed tributary to a deeper cross valley. In the latter case the deeper cross valley was interpreted to have eroded headward across flow moving along the barbed tributary alignment to and then across the present-day divide crossing. Closely spaced divide crossings with converging valleys on both sides were interpreted to have been eroded by diverging and converging flood flow channels in a flood formed anastomosing channel complex that once crossed the modern-day drainage divide. All such interpretations were further checked for their consistency with similar interpretations made at other nearby drainage divides.

The first Missouri River drainage basin systematic topographic map study used mosaics of detailed hard copy topographic maps and was conducted during the 1999-2001 time period and produced unexpected results that could not be demonstrated to skeptical reviewers. The second study was conducted during the 2011-2013 time period and used National Geographic TOPO software and maps. More than 500 research notes in blog format describing the origins of approximately 4000 drainage divides can be found at geomorphologyresearch.com. The detailed topographic map evidence observed in both studies suggested diverging and converging channel complexes had once crossed all Missouri River drainage basin drainage divides and for that reason the new paradigm defining rule is all Missouri River drainage basin valleys (of any size) eroded headward across massive south- and southeast-oriented floods. The new paradigm rule forces recognition of a large North American continental ice sheet that deeply eroded the bedrock underneath it (the accepted paradigm does not recognize deep continental ice sheet erosion in the Northern Plains region) and that was heavy enough to cause crustal warping that raised mountain ranges and plateaus as huge meltwater floods flowed across them (the accepted paradigm does not recognize the flood erosion evidence and does not see a relationship between mountain range and plateau uplift and the presence of a continental ice sheet).

The study reported here used detailed topographic maps available at the USGS National Map website and began by looking for and identifying unusual erosional landform features, major drainage divides, barbed tributaries, asymmetric drainage divides, and obvious divide crossings. Local relief in upland areas surrounding the North and South Platte River confluence area is limited (except in sand dune areas) and regional slopes and tributary lengths were used in addition to the divide crossings to determine how the asymmetric divides originated. Orientations and spacings of tributaries to the North and South Platte Rivers and to their major tributaries suggested how the barbed tributaries formed. In each case an effort was made to explain the observed erosional landform features from both the accepted and the new paradigm perspectives. Accepted paradigm interpretations of the observed map evidence, to the extent possible, were based on published literature and emphasized the importance of prevailing winds from the northwest, climate changes, and of some possible local structural features. New 
paradigm interpretations assumed massive south-and southeast-oriented meltwater floods had flowed across the region and considered the possibility the floods may have consisted of large sheets of water moving slowly across a low relief and gently sloping and almost featureless plain prior to headward erosion of the deep Platte, North Platte and South Platte River valleys.

\section{Results}

\subsection{South Platte River-Republican River Asymmetric Drainage Divide}

The asymmetric South Platte River-Republican River drainage divide is a North and South Platte River confluence area geomorphic feature much too important to be ignored. The divide location is shown in figure 2 (except where it is located in a sand dune area). To the east of the North and South Platte River confluence area the asymmetric divide continues between the Platte and Republican River drainage basins to the Platte River bend (at the east edge of figure 1) where a similar asymmetric divide between the Platte River and Big Blue River drainage basins begins. Long southeast-oriented (and intermittent) Republican River tributaries seen in figure 2 begin almost along the South Platte River valley edge and flow across a low relief surface sloping gently to the southeast. Short northwestoriented and longer southeast-oriented drainage routes (a few seen in figure 2) join the northeast-oriented South Platte River as barbed tributaries. Between the two rivers southeast-oriented headwaters join north-oriented Rush Creek and Ash Hollow as barbed tributaries and Rush Creek and Ash Hollow also join the southeast-oriented North Platte River as barbed tributaries. Applying the principle of cross cutting relationships to the drainage patterns seen in figure 2 (better seen on detailed maps) the northeast-oriented South Platte River valley and the north-oriented Ash Coulee and Rush Creek valleys are cut across previous southeast-oriented drainage, although details vary depending on the paradigm used.

Wayne (1985, p. 112), who worked from the accepted paradigm perspective, states "The present drainage basin of the Platte River in Nebraska is highly asymmetrical.... East of its junction with the South Platte River, nearly all the tributaries of the Platte join from the north, and the divide between the Platte and the Republican lies almost along the rim of the Platte's south valley wall." While suggesting the North Platte River was Nebraska's Early Pleistocene master stream and had at that time extended eastward into Iowa, Wayne notes (p. 111) as result of early Pleistocene glaciations "a thick blanket of gravelly sand had accumulated across eastern Nebraska [and] the course of the Platte changed several times during that period" and (p. 116) "Part of the ice-marginal drainage went southward through the Big Blue River basin." While implying (but not saying) the Platte-Big Blue River asymmetrical drainage divide originated when the Platte River valley cut across south-oriented ice-marginal drainage to the Big Blue River, Wayne's explanation focuses on single drainage routes and does not describe large sheets of meltwater nor does it offer an explanation for the origin of the higher elevation Platte (and South Platte) River asymmetrical drainage divide with the Republican River.

In contrast the new paradigm requires all valleys (of any size) within the Missouri River drainage basin to have eroded headward across or along south- and southeast-oriented floods and the Platte River and the North and South Platte River valleys to have eroded headward across large floods. Under such a scenario the North and South Platte River confluence area low relief and gently sloping upland surface was probably carved by vast slow-moving sheets of water flowing towards an actively eroding (and deep) Republican River valley. Headward erosion of the southeast-oriented Platte River valley (from the bend at the figure 1 east edge) toward the North and South Platte River confluence area with its much lower base level progressively captured the southeast-oriented flood flow and in doing so created the asymmetric Platte-Republican River drainage divide. Because the actively eroding Platte River valley floor was roughly 100 meters lower in elevation than the gently sloping and low relief upland surface floodwaters located on the upland surface and to the south of the newly eroded Platte River valley reversed their flow direction and moved in a north direction to erode what are today numerous north-oriented (and barbed) tributary valleys draining into the southeast-oriented Platte River valley (located between the North and South Platte River confluence and the Platte River bend).

The actively eroding southeast-oriented Platte River valley head when it progressed west of actively eroding and deep south-oriented Republican River tributary valleys diverted the slowly moving sheets of water in what is now the North and South Platte River confluence area in an east direction, which carved shallow east-oriented channels leading to the actively eroding Platte River valley head. Once in the North and South Platte River confluence area the Platte River valley head split with one branch eroding headward along one east-oriented channel and another branch eroding headward along a parallel east-oriented channel just to the north. Erosion of the southern valley head first carved what is now the east-oriented South Platte River valley segment and then turned to erode headward in a southwest direction so as to better capture southeast-oriented flood flow moving to the Republican River valley and to erode the northeast-oriented South Platte River valley. South Platte River valley headward 
erosion for the entire distance seen in figure 2 captured southeast-oriented sheets of water moving toward the Republican River valley and created the asymmetric South Platte-Republican River drainage divide. Southeastoriented flood flow moving into the newly eroded South Platte River valley carved short southeast-oriented (and barbed) tributary valleys and reversals of flow on the low relief upland surface carved short northwest-oriented (and barbed) tributary valleys. The Lodgepole Creek bend seen in figure 2 was created when headward erosion of a southeast-oriented tributary valley captured a shallow channel carved by floodwaters moving in an east direction.

\subsection{Valleys (Divide Crossings) Notched into the North-South Platte River Drainage Divide}

Remarkable NW-SE oriented linear features seen in figure 3 cross the interfluve between the North and South Platte Rivers in a region south of present-day Lake McConaughty. Previous investigators (e.g. Diffendal, 1994) attribute these linear features to prevailing winds from the northwest and a shallow NW-SE oriented depression (at the figure blue number 1) and other shallow depressions seen on more detailed maps support that interpretation. However, the figure also shows another unusual asymmetric drainage divide. The North Platte-South Platte River drainage divide roughly follows the southeast-oriented North Platte River valley edge and is a water eroded feature. Figure 3 provides a set of easily interpreted landform features. Most important, there is the southeast-oriented gently sloping and low relief upland surface between the North and South Platte River valleys with elevations exceeding 1140 meters in the figure northwest corner and less than 1100 meters along the South Platte River valley rim. That sloping upland surface is a northern continuation of the sloping upland surface found to the south of the South Platte River valley, which has been cut into that gently sloping upland surface.

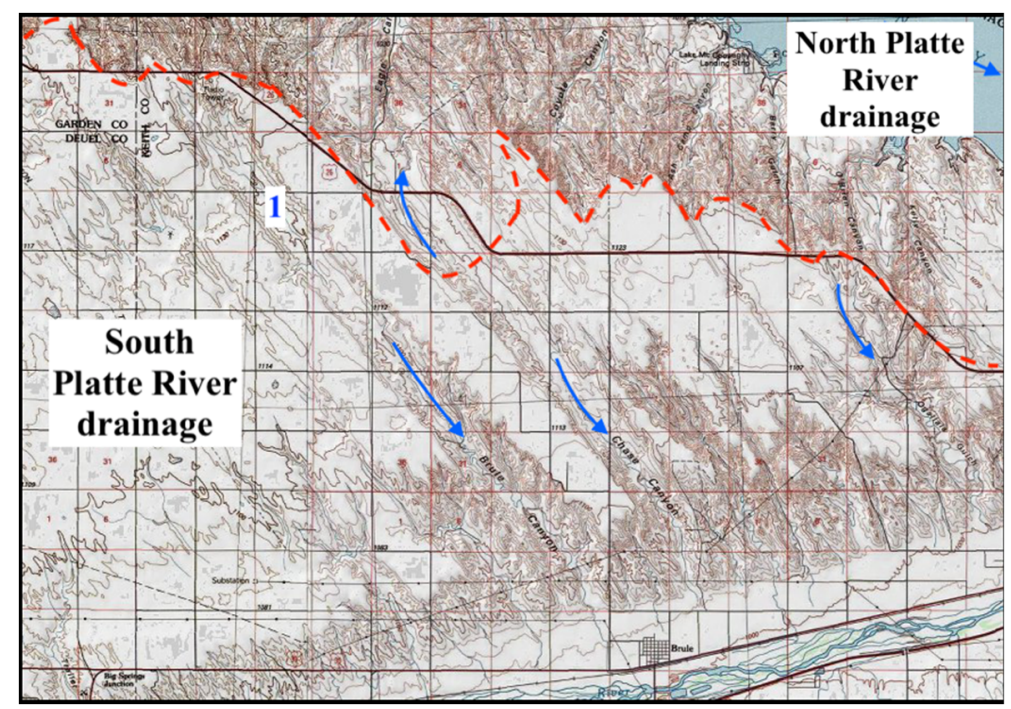

Figure 3. Modified topographic map from USGS National Map website showing interfluve between North and South Platte Rivers. Red dashed line shows the approximate drainage divide position. The blue number 1 identifies a shallow NW-SE oriented depression. Sides of squares in the grid are 1 mile $(1.6 \mathrm{~km})$ in length. Contour interval is 10 meters

While prevailing winds may have created the shallow depressions and some of the upland surface linear features, prevailing winds did not create the southeast-oriented gently sloping upland surface or the asymmetric drainage divide and prevailing winds did not erode the North and South Platte River valleys. Published (accepted paradigm) interpretations at least to date do not provide simple explanations for how the North and South Platte River valleys originated and do not provide any explanation for the asymmetric drainage divide or for the southeast-oriented slope seen in figure 3 . The southeast-oriented slope is consistent with the new paradigm requirement that the North and South Platte River valleys eroded headward across (or along) immense southeast-oriented floods and just as slow-moving sheets of water explain the South Platte River-Republican River asymmetric drainage divide they also explains the North Platte River-South Platte River drainage divide seen in figure 3. Southeast-oriented sheets of water moving into a newly eroded South Platte River valley also explain the southeast-oriented South Platte River tributary valleys and the northwest to southeast oriented upland surface linear features and do not rule out the possibility of subsequent wind erosion and deposition. In addition, the slow-moving southeast-oriented sheets of water also explain the southeast-oriented headwaters flowing to north-oriented Ash Hollow and Rush Creek seen in Figure 2. 


\subsection{Narrow Drainage Divide between Parallel and Adjacent East-Oriented Rivers}

Another unusual North and South Platte River confluence area feature is how the northeast-oriented South Platte River becomes an east-oriented river before joining the southeast-oriented North Platte River, which has also become an east-oriented river. For approximately 70 kilometers after turning in east directions these two rivers flow almost adjacent to each other and for approximately 50 kilometers of that distance there is a well-defined and narrow interfluve, which for a considerable distance is as high or almost as high as the gently sloping upland surfaces on either side of the confluence area. The Platte River, which is formed where the east-oriented North and South Platte Rivers finally come together, flows for approximately 120 kilometers in the same southeast direction the North Platte River had been flowing further to the west (see figure 1). In addition to flowing in separate, but adjacent east-oriented valleys at least some drainage from the interfluve flows in a northwest direction to join the east-oriented North Platte River (see figure 4). The interfluve, which gradually narrows and decreases in elevation in an eastward direction is also crossed by numerous shallow divide crossings (best seen on topographic maps more detailed than in figure 4) suggesting what were probably numerous and closely spaced channels of southeastoriented water once spilled across the divide.

Except near its eastern end high points along the loess covered interfluve are as high or slightly higher in elevation as elevations along the South Platte River-Republican River drainage divide and similar to elevations north of the North Platte River valley (although loess and sand dunes make exact comparisons from the topographic maps difficult). The two adjacent and parallel east-oriented river valleys must have eroded separately into what is now a regional low relief and gently sloping upland bedrock surface. The question arises, how can two major river valleys be eroded almost adjacent to each other on an almost featureless plain? Condon (2005, p. 54) working from the accepted paradigm perspective notes during the Pliocene and Pleistocene "Nebraska became the locus of deposition of much of the material eroded from the Front Range, Laramie Range, and Medicine Bow Mountains" and suggests for the downstream southcentral Nebraska Platte River the "valley was superimposed on the river." He argues "Prior to deposition of Peoria Loess the Platte was flowing, generally unconfined by valley walls, on a relatively flat alluvial plain... [and] the Peoria Loess and later eolian units were superimposed on the river, and the Platte was essentially confined by loess to its valley in south central Nebraska." While loess and sand dunes are present on upland areas surrounding the North and South Platte River confluence area, geologic maps show both river valleys are eroded into the Ogallala Formation and the North Platte River valley to be also eroded into the underlying Brule Formation and unless the Ogallala and Brule Formations were deposited around the two rivers Condon's explanation does not explain the North and South Platte River confluence area valleys.

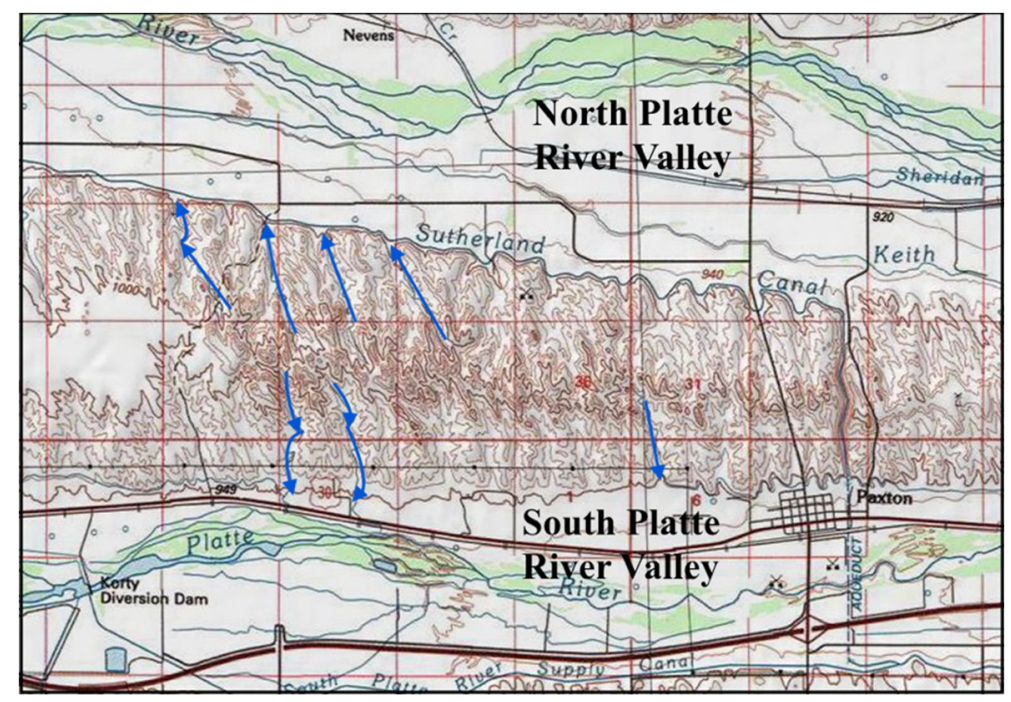

Figure 4. Modified topographic map from USGS National Map website showing drainage divide between parallel and adjacent North and South Platte Rivers. Blue arrows emphasize some drainage divide area drainage routes. Sides of grid squares are 1 mile (1.6 kilometers) in length. Contour interval is ten meters

An alternate explanation from the new paradigm perspective is the two adjacent east-oriented river valleys originated as shallow east-oriented channels carved by slow moving southeast-oriented sheets of water that had been diverted toward the actively eroding southeast oriented Platte River valley head (to the east of the presentday North and South Platte River confluence). The deep and actively eroding Platte River valley head then split as described with one valley head eroding westward and southwestward to carve the South Platte River valley. At the 
same time the other valley head eroded headward along an adjacent east-oriented channel as it captured southeastoriented sheets of water moving toward the actively eroding South Platte River valley head and then eroded headward in a northwest direction along flood flow being diverted in a southeast direction by the rising Laramie Range (in Wyoming). At that time rising Rocky Mountain ranges were trapping south-oriented floodwaters with the trapped floodwaters forced to spill eastward across the rising Laramie Range in a large anastomosing channel complex (described in Clausen, 2020a) with North Platte River valley headward erosion also capturing the eastoriented anastomosing channel complex's northern half and further to the northwest beheading and reversing south-oriented flood flow that had been flowing across the Laramie Range's northern section (see Clausen 2019a). At the same time South Platte River valley headward erosion captured the large east-oriented anastomosing channel complex's southern half and then eroded southwestward to capture additional east- and southeast-oriented floodwaters that were spilling across the rising Front Range (see Clausen 2020b).

\section{Discussion}

There can be no question the North and South Platte River confluence area low relief and gently sloping southeastoriented upland surface, asymmetric drainage divides, divide crossings, and barbed tributaries are easier to explain by headward erosion of deep valleys across large and slow-moving southeast-oriented sheets of water and that the interfluve between the east-oriented North and South Platte River segments is easier to explain by parallel valley headward erosion along shallow flood flow channels than by any of the varied explanations in previously published literature. Further, while the accepted paradigm has yet to explain many upstream North and South Platte River drainage system features a growing number of published papers use the new paradigm to explain numerous previously unexplained North and South Platte River upstream drainage features. However, the North Platte and South Platte River confluence area location is south of the Nebraska Sand Hills and north of several smaller sand dune fields and is also near the western margin of extensive central and eastern Nebraska loess deposits which has suggested to previous investigators that arid conditions and aeolian processes played significant roles in shaping western Nebraska surface landforms, although those suggestions have not led to any agreement as to how most larger-scale western Nebraska landforms developed.

For example, Muhs et al (2008, p 1380) comment "the origin of Peoria Loess in the Great Plains of Nebraska, Kansas, and Colorado has been studied for more than six decades, at present there is no consensus on its genesis....Peoria Loess in the Great Plains has no clear link to outwash of the Laurentide ice sheet, except possibly in that part of Nebraska adjacent to the Missouri River. Previous workers proposed a variety of sources for the loess in the Great Plains, including Platte River alluvium (including glacial outwash from the Rocky Mountains); glacial outwash from the Missouri River; sediments from the Tertiary Ogallala, Arikaree, and White River Groups; and sediment from the Nebraska Sand Hills or other dune fields." Their own work (p. 1378) shows that "the finegrained silts were transported episodically through the Nebraska Sand Hills from Tertiary and Cretaceous bedrock sources to the north" and was in agreement with Mason (2001, p. 79) who states "A strong northwest to southeast thickness trend indicates that most Peoria Loess in Nebraska was transported from one or more unglaciated northwestern source areas rather than from unglaciated influenced river floodplains" and who argues that Peoria Loess deposition on the central Great Plains was largely a direct response to climatic change. Interestingly, while these loess source areas are consistent with prevailing wind directions the source areas are also consistent with the new paradigm's flood flow directions.

Almost all $20^{\text {th }}$ and $21^{\text {st }}$ century researchers consider loess deposits (including most Nebraska loess deposits) to be primarily wind deposited sediment. However, looking back at the history of loess research Ding (2018, p. 45) says in the mid 1830s and 1840s "Lyell introduced loess research from the Rhine valley to Britain. At the same time, Lyell put forward the theory of the fluvial origin of loess and verified his theory by expanding study areas to the United States. In 1866, Pumpelly, the first foreign geologist investigating Chinese loess, put forward lacustrine formation of loess. Pumpelly's hypothesis was soon argued against in 1870 by F. von Richthofen (1833-1905), who thought [the Chinese] loess was formed via an aeolian mode.” Among von Richthofen's arguments were the presence of loess at elevations well above present day river floodplains and lakes, a lack of stratification, and the imbedding of land shells and bones of terrestrial mammals. By the late $19^{\text {th }}$ century most American researchers had become convinced wind transport and deposition were responsible for most loess deposits (including most if not all Nebraska loess deposits) although source areas and other details are still debated.

Today an aeolian origin for most loess deposits is an important accepted paradigm interpretation, yet as the history of loess research makes evident early workers described loess as being fluvial or lacustrine in origin. It was only after accepted paradigm interpretations did not provide a way to explain how fluvial or lacustrine processes could transport and then deposit the loess in places like central and western Nebraska that researchers adopted the aeolian origin hypothesis. The new paradigm requires massive, but sometimes slowly moving south- and southeast- 
oriented ice sheet meltwater floods to have flowed across what is now Nebraska which would have been between a continental ice sheet in the east and the rising Rocky Mountains to the west. Temporary "ponding" of such floodwaters could have resulted in a large western Nebraska deltaic sandy deposit while the slow-moving floodwaters deposited finer-grained silt size materials in central and eastern Nebraska. Details of how such floods transported and then deposited sands that now make up the Nebraska Sand Hills and the finer-grained sediments in the Nebraska loess deposits are beyond the scope of this paper. However, the new paradigm's ability to explain the regional asymmetric drainage divides, the confluence area's gently sloping southeast-oriented upland surface, the barbed tributaries, and many upstream North and South Platte River drainage system features suggests the Nebraska Sands Hills could be located on a large sandy deltaic deposit and also that, in spite of being rejected for more than a century, early investigator interpretations may have been correct and much, if not all, of Nebraska's loess was transported and deposited by large south- and southeast-oriented meltwater floods.

While this paper demonstrates the new paradigm required floods successfully explain North and South Platte River confluence area drainage features (features the accepted paradigm has yet to explain) it should be remembered paradigms are fundamentally different sets of rules and assumptions, which by themselves are neither correct nor incorrect. For this reason, the accepted and new paradigms lead to fundamentally different middle and late Cenozoic geologic and glacial histories, although the observable geologic evidence that must be explained is the same regardless of which paradigm is being used. For example, in the case of North American glacial history both paradigms see evidence for a former north-oriented drainage system that once extended from northern Wyoming and northwestern South Dakota across Montana, North Dakota, and Canada to what is now the Hudson Bay region, but the accepted paradigm interprets that drainage system to be pre-glacial in age (Jackson, 2018) while the new paradigm interprets that drainage system to have formed on the floor of a large continental ice sheet that deeply eroded the underlying bedrock (Clausen, 2019b). The two paradigms require fundamentally different glacial histories with the accepted paradigm describing multiple thin ice sheets that did not erode the underlying Tertiary age valleys while the new paradigm's ice sheet was heavy enough to not only deeply erode the underlying bedrock but also to raise mountain ranges and plateaus as large meltwater floods flowed across them. One paradigm cannot be used to judge the other, instead the two paradigms need to be compared according to very basic scientific rules such as which paradigm explains the observed evidence in the simplest ways and which paradigm results in explanations that are consistent with each other?

\section{Conclusions}

Detailed topographic maps of the North and South Platte River confluence area show asymmetric drainage divides, multiple barbed tributaries, shallow divide crossings, a gently sloping and low relief southeast-oriented upland surface, and a unique and narrow interfluve between two nearly adjacent east-oriented river segments. Massive sheets of slow-moving water probably shaped the gently sloping and low relief southeast-oriented regional upland surface as the water flowed to what at that time was the newly eroded Republican River valley. Headward erosion of the southeast-oriented Platte River valley segment (downstream from the confluence) next captured the slowly moving sheets of water by first eroding in a northwest direction and then splitting to erode headward in west directions along what were probably adjacent and shallow east-oriented channels that had been eroded by water moving toward the actively eroding Platte River valley head. Headward erosion along the northern east-oriented channel (now the North Platte River) immediately followed headward erosion along the southern east-oriented channel (now the South Platte River). After eroding westward for approximately 70 kilometers headward erosion along the northern channel (now North Platte River) turned in a northwest direction to erode headward along flood flow that had been diverted in a southeast direction by the rising Laramie Range and the southern channel turned to erode headward in a southwest direction so as to capture east-oriented flood flow spilling across the rising Laramie and Front Ranges. This confluence area drainage system history as determined from detailed topographic maps is consistent with recently published new paradigm interpretations of the upstream North and South Platte River drainage histories, however is not consistent with many accepted paradigm middle and late Cenozoic regional geologic and glacial history interpretations. While much further work is needed the new paradigm does permit detailed topographic map drainage system evidence in the North and South Platte River confluence area to be interpreted in an internally consistent manner that is also consistent with new paradigm interpretations of upstream North and South Platte River drainage system history.

\section{Acknowledgements}

Preliminary work leading to the new paradigm was done while employed as a faculty member at Minot State University (North Dakota) where other faculty members, library staff, and students helped provide access to needed topographic maps. During the mid 1960s Arthur Strahler, then at Columbia University, and Brainerd Mears, Jr., then at the University of Wyoming, introduced the author to numerous unsolved drainage history problems. 


\section{Conflict of interests}

The authors declare that there is no conflict of interests regarding the publication of this paper.

\section{Reference}

Ahlbrandt, T. S., \& Fryberger, S. G. (1980). Eolian Deposits in the Nebraska Sand Hills. United States Geological Survey Professional Paper, 1120-A, 1-24.

Burchett, R. R. (1986). Geologic Bedrock Map of Nebraska. University of Nebraska Conservation and Survey Division, Geologic Maps and Charts 1, scale 1:1,000,000.

Clausen, E. (2017). Origin of Little Missouri River-South Fork Grand River and nearby drainage divides in Harding County, South Dakota and adjacent eastern Montana, USA. Open Journal of Geology, 7, 1063-1077. https://doi.org/10.4236/ojg.2017.78071

Clausen, E. (2018a). Belle Fourche River-Cheyenne River drainage divide area in the Wyoming Powder River Basin analyzed by topographic map interpretation methods, USA. Journal of Geography and Geology, 10, 116. https://doi.org/10.5539/jgg.v10n2p1

Clausen, E. (2018b). Topographic map analysis of Laramie Range bedrock-walled canyon complex and the Goshen Hole escarpment-surrounded basin, Albany and Platte Counties, southeast Wyoming, USA. Open Journal of Geology, 8, 33-55. https://doi.org/10.4236/ojg.2018.81003

Clausen, E. (2019a). Use of stream and dismembered stream valleys now crossing Wyoming's northern Laramie Mountains to test a recently proposed regional geomorphology paradigm, USA. Open Journal of Geology, 9, 731-751. https://doi.org/10.4236/ojg.2019.911087

Clausen, E. (2019b). How a fundamentally different and new glacial history paradigm explains North America's glaciated prairie region erosional escarpments and drainage patterns. Earth Science Research, 8(2), 23-34.

Clausen, E. (2020a). Use of detailed topographic map evidence of the southeast Wyoming Gangplank area to compare two fundamentally different geomorphology paradigms, USA. Open Journal of Geology, 10, 261279. https://doi.org/10.4236/ojg.2020.104014

Clausen, E. (2020b). Topographic map analysis of mountain passes crossing the Continental Divide between Colorado River headwaters and North and South Platte River headwaters to test a new geomorphology paradigm. Journal of Geography and Geology, 12(1), 50-64. https://doi.org/10.5539/jgg.v12n1p50

Clausen, E. (2020c). Use of topographic map evidence from drainage divides surrounding Wyoming's Great Divide Basin to compare two fundamentally different regional geomorphology paradigms. Earth Science Research, 9(1), 45-57.

Condon, S. M. (2005). Geologic Studies of the Platte River, South-Central Nebraska and Adjacent Areas-Geologic Maps, Subsurface Study, and Geologic History. United States Geological Survey Professional Paper, 1706, 63. https://doi.org/10.3133/pp1706

Diffendal, R. F. Jr. (1980). The Rush Creek-Lisco structural basin, Garden and Morrill Counties, Nebraska. Transactions of the Nebraska Academy of Sciences, VIII, 123-130.

Diffendal, R. F. Jr. (1991). Geologic map showing configuration of the bedrock surface, North Platte, $1^{\circ} \times 2^{\circ}$ degrees Quadrangle, Nebraska. United States Geological Survey, Miscellaneous Investigations Series Map I-2277, scale 1:250,000.

Diffendal, R. F. Jr. (1994). Geomorphic and structural features of the Alliance $1^{\circ}$ x $2^{\circ}$ Quadrangle, Western Nebraska, discernible from synthetic-aperture radar imagery and digital shaded-relief maps. University of Wyoming Contributions to Geology, 30, 137-147.

Ding, H., Yanrong, L., Yang, Y., \& Xia, J. (2019). Origin and evolution of modern loess science - 1824 to 1964. Journal of Asian Earth Science, 170, 45-55. https://doi.org/10.1016/j.jseaes.2018.10.024

Flint, R. F. (1955). Pleistocene Geology of Eastern South Dakota. United States Geological Survey Professional Paper, 262, 173. https://doi.org/10.3133/pp262

Jackson, L. (2018). The Paleo-Bell River: North America's vanished amazon. Earth, 63(7/8), 74-81.

Kuhn, T. (1970). The Structure of Scientific Revolutions (2nd ed., p. 210). University of Chicago Press, Chicago.

Mason, J. A. (2001). Transport direction of Peoria Loess in Nebraska and implications for loess sources on the Central Great Plains. Quaternary Research, 56(1), 79-86. https://doi.org/10.1006/qres.2001.2250 
Muhs, D. R., \& Wolfe, S. A. (1999). Sand dunes of the northern Great Plains of Canada and the United States. In D. S. Lemmen, \& R. E. Vance (Eds), Holocene Climate and Environmental Change in the Pallister Triangle: A Geoscience Context for Evaluating the Impacts of Climate Change on the Southern Canadian Prairies. Geological Survey of Canada Bulletin, 534, 183-197. https://doi.org/10.4095/211117

Muhs, D. R., Bettis, E. A. III, Aleinkoff, J. N., McGeehin, J. P., Beann, J., Skipp, G. Marshall, B. D., Poberts, H. M., Johnson, W. C., \& Benton, R. (2008). Origin and paleoclimatic significance of Late Quaternary loess in Nebraska: evidence from stratigraphy, chronology, sedimentology, and geochemistry. Geological Society of America Bulletin, 120(11/12), 1378-1407. https://doi.org/10.1130/B26221.1

Muhs, D. R., Swinehart, J. B., Loope, D. B., Been, J., Mahan, S. A., \& Bush, C. A. (2000). Geochemical evidence for an eolian sand dam across the North and South Platte Rivers in Nebraska. Quaternary Research, 53, $214-$ 222. https://doi.org/10.1006/qres.1999.2104

Pabian, R. K., Diffendaj, R. F. Jr., \& Gould, F. (1981). Geology of Lake McConaughy Area Keith County, Nebraska (p. 228). Papers in Natural Resources University of Nebraska.

Russell, W. L. (1929). Drainage alignment in the western Great Plains. Journal of Geology, 37, 249-255. https://doi.org/10.1086/623618

Scott, G. R. (1978). Map showing geology, structure, and oil and gas fields in the Sterling $1^{\circ} \times 2^{\circ}$ Degrees Quadrangle, Colorado, Nebraska, and Kansas. United Stated States Geologic Survey Miscellaneous Investigations Series Map I-1092, Scale 1:250,000.

Swinehart, J. B., \& Diffendal, R. F. Jr. (1997). Geologic map of the Scottsbluff $1^{\circ} x 2^{\circ}$ Quadrangle, Nebraska and Colorado. United States Geologic Survey, Geologic Investigations Series Map 1-2545, scale 1:250,000.

Swinehart, J. B., Souders, V. L., DeGraw, H. M., \& Diffendal, R. F. Jr. (1985). Cenozoic paleogeography of western Nebraska. In R. M. Flores, \& S. S. Kaplan (Eds), Cenozoic Paleogeography of West-Central United States (pp. 209-229). Rocky Mountain Section-S.E.P.M., Denver, Colorado.

Thornbury, W. D. (1965). Regional Geomorphology of the United States (p. 609). John Wiley and Sons, New York. https://doi.org/10.1097/00010694-196508000-00018

Wayne, W. J. (1985). Drainage patterns and glaciations in eastern Nebraska. Institute for Tertiary-Quaternary Studies-TER-QUA Symposium Series 1, 111-117.

\section{Copyrights}

Copyright for this article is retained by the author(s), with first publication rights granted to the journal.

This is an open-access article distributed under the terms and conditions of the Creative Commons Attribution license (http://creativecommons.org/licenses/by/4.0/). 